\title{
HEALTH BEHAVIOUR AND SCHOOL ENVIRONMENT AMONG SCHOOL-AGED BLACK AND WHITE SOUTH AFRICAN CHILDREN IN THE LIMPOPO PROVINCE
}

\author{
Prof. Karl Peltzer \\ Health Behaviour Research Unit, University of the North \\ Corresponding author: peltzerk@mweb.co.za
}

Keywords: health behaviour; Limpopo Province; school-aged children; school environment; South Africa

\section{SUMMARY}

The main objective of the 'Health Behaviour among School-Aged Children' (HBSC) study was to collect information on health-related behaviour of South African youth. Another objective was to examine the association between learners' perceptions of their school environment, teachers' and peers' support and their health behaviours. Furthermore, recommendations about the health behaviour of school-aged children are developed. The sample comprised 515 Grade 8 secondary school learners chosen at random from three urban schools in the Polokwane area, Limpopo Province. Results indicated that learners who had positive perceptions regarding their school environments were significantly more likely to engage in health promoting behaviours. The healthy food score was associated with supportive teachers but not with supportive peers and supportive parents and socioeconomic status. Regarding the different health-related behaviours, gender differences were less pronounced than racial differences. Black school-aged children had a significantly higher unhealthy food score than Whites but there were no racial differences on the healthy food score. In conclusion, therefore health promotion practitioners need to consider the impact of the school environment (particularly unrealistic scholastic expectations from teachers and parents) on health behaviours of school-aged children.

\section{OPSOMMING}

Die hoofdoelwit van die studie "Health Behaviour among School-aged Children" (Gesondheidsgedrag van skoolgaande kinders) studie is om inligting in te samel ten opsigte van gesondheidverwante gedrag van die SuidAfrikaanse jeug. Nog ' $n$ doelwit is om inligting te bekom ten opsigte van die verwantskap tussen leerders se persepsies van hul skoolomgewing, ondersteuning van hul onderwysers en portuurgroepe enersyds en hul gedrag andersyds. Verder is aanbevelings oor die gesondheidsgedrag van skoolgaande jeug gemaak. Die steekproef het bestaan uit 515 Graad 8 leerders van sekondêre skole wat ewekansig gekies is uit drie stedelike skole in die Polokwane omgewing in die Limpopo Provinsie. Resultate toon dat leerders wat positiewe persepsies het ten opsigte van hul skoolomgewing, beduidend meer geneig is om betrokke te wees in gesondheidsbevorderlike gedrag. Die gesondekos-telling is geassosieer met ondersteunende onderwysers, maar nie met ondersteunende portuurs, ondersteunende ouers en sosio-ekonomiese status nie. Ten opsigte van verskille in gesondheidsverwante gedrag, is geslagsverskille minder beduidend as rasseverskille. Swart kinders van skoolgaande ouderdom het beduidend hoër tellings op 'n skaal van ongesonde kos behaal in vergelyking met blankes, terwyl daar geen verskil tussen tellings vir die twee rasse was op die skaal vir gesonde kos nie. Ter samevatting: gesondheidsbevorderingpraktisyns moet die impak van die skoolomgewing (veral ten opsigte van onrealistiese skolastiese verwagtings van ouers en onderwyseres) op die gesondheidsgedrag van die jeug in berekening bring. 


\section{INTRODUCTION}

In 1988, the proportion of deaths due to chronic diseases of lifestyle was $24.5 \%$ of all South African deaths and $28.5 \%$ of death among those aged $35-64$ years (Bradshaw, Bourne, Schneider \& Sayed, 1995:7). The major causes of death contributing to these figures were cerebrovascular diseases $(7.2 \%$ of all deaths) and ischaemic heart disease ( $8.7 \%$ of all deaths). In a recently nationally representative survey the Medical Research Council (1998:12-15) found that among persons above 15 years $11 \%$ of men and $13 \%$ of women were found to either have a blood pressure above $160 / 95 \mathrm{mmHg}$ or were taking appropriate medication to lower their blood pressure. A calculation based on these prevalence rates and the census figures published for the South African population 15 years and older leads to an estimate of about 3.3 million hypertensive people in the country. Moreover, $25 \%$ of South Africans fell into the overweight category, while $20 \%$ fell into the obese category; at 30\%, black women have the highest incidence of obesity, $10 \%$ of children under the age of two, and $20 \%$ of children under the age of six are overweight. For South Africa as a whole, lung cancer already accounts for $24 \%$ of all deaths from cancer in men, and $10.6 \%$ of all such deaths in women. In 1995, in the Limpopo Province, 38\% of African men and $2.1 \%$ of African women were current smokers. In the same study the national current smoker averages for African men and women were $53 \%$ and $10 \%$ respectively (Reddy, Meyer-Weitz \& Yach, 1996:1389). The two most predominantly currently (past month) used substances among urban secondary school learners (mean age=19.1 years) in the Limpopo Province of South Africa were alcohol (41.9\% in men and $34.3 \%$ in women) and tobacco (23.3\% in men and $25.7 \%$ in women) according to Peltzer, Cherian and Cherian (1999:51). Flisher, Ziervogel, Chalton, Leger and Robertson (1993b:477) found among Cape Peninsula high-school learners (Grades 8 to 12 ) that $18.1 \%$ smoked at least one cigarette per day, $26.2 \%$ had used alcohol recently (Flisher, Ziervogel, Chalton, Leger \& Robertson, 1993a:480). Data from a national demographic and health survey in South Africa (Medical Research Council, 1998:27) revealed that the prevalence of smoking among teenage boys was high. About one in seven teenage boys smoked cigarettes daily or occasionally. The prevalence was lower among teenage girls. Overall, ten percent of all teenagers smoked.
Similarly, Warren, Riley, Asma, Erikson, Green, Blanton, Loo, Batchelor and Yach (2000:611) found among South African school children aged 13 to 15 years that cigarette smoking (at least one in the past month) had a median of $17.6 \%$ and other tobacco products $11.8 \%$. Further, Flisher and Chalton (2001:243) found among Black high school learners in the Cape Peninsula that urbanisation was associated with an increase in the prevalence of some risk behaviours (use in the previous month of alcohol, cannabis, and cannabis mixed with Mandrax, being a victim of violence, perpetration of an act of violence and suicidal tendencies). While the full aetiology of any of these diseases has yet to be understood, behavioural factors such as tobacco use, exercise, diet, alcohol consumption and preventive health checks are strongly implicated as risk factors impacting on chronic diseases of lifestyle (Steptoe \& Wardle, 1992:485).

There appears to be a lack of studies on other health behaviours such as diet, physical activity, oral hygiene, seat belt use and injury in the South African context. Graham and Uphold (1992:77) studied health perceptions, safety, lifestyle practices, nutrition, dental health and care of minor injuries among school-aged boys and girls. Findings indicated that most boys and girls viewed themselves to be healthy and managed their own care fairly well in the areas of seat belt use, exercise and dental health. Nutrition was identified as an area of concern, with $10 \%$ of the children skipping breakfast and more than $50 \%$ eating snacks with empty calories. Generally, children were found to be knowledgeable about the management of simple injuries and how to respond in the event of an emergency. Boys and girls were similar in all areas of health perceptions and behaviours except for dental health, with boys reporting more regular visits to the dentist than girls did (Graham \& Uphold, 1992:77). Adolescence, in particular, seems to be a very important period, because it is the time when people are looking for, experimenting with and also establishing, their lifestyle, attitudes, concepts, beliefs and habits that may have long-term influences on their health (Geckova, Tuinstra, Pudelsky, Kovarova, Van Dijk, Groothoff \& Post, 2001:635). The rapid social, physical and mental development occurring during adolescence is important as many of the health behaviours, which become manifest in adulthood, such as smoking, have their origins during younger years. The use of illicit drugs and alcohol and 
other forms of risk taking during adolescence may not only have an immediate impact on morbidity and mortality, but may also contribute to actions which cause injuries. Thus, behaviours such as tobacco use, food choices and physical activity are also measured as indicators of adolescent "health" because of their importance as determinants of future health status such as a cause of chronic diseases including heart disease and cancer (Nutbeam, 1997:10).

King, Wold, Tudor-Smith and Harel (1996:15ff.) reported that on the basis of data from surveys of adolescents across Europe participating in the 'Health Behaviour among School-Aged Children' (HBSC) study indicated that a "supporting and accepting school atmosphere can contribute to the health and happiness of young people". Learners satisfied with school were less likely to smoke or to drink in excess, were more likely to have positive relationships with teachers, parents and peers; and were more likely to feel healthy. Similarly, Resnick, Bearman, Blum, Nauman, Harris, Jones, Tabor, Beuhring and Udry (1997:223) identified among a cross-sectional national US study that family and school contexts such as parental expectations, parent-family connectedness, perceived school connectedness and whether or not a parent was on welfare, as well as individual characteristics, were associated with health and risk behaviours among adolescents. Thus, young people are apparently influenced by their perceptions of how their teachers view them and their interactions with teachers, suggesting that the classroom atmosphere, created by teachers, is reportedly important (King et al. 1996:18). Acceptance by peers is also important to young peoples' social development, with peer influence being one of the most consistently reported factors affecting adolescent substance use (Bruvold, 1993:872). Bronfenbrenner (1979:15-20) suggests that meso-level systems may be investigated for the effect of interrelations between two or more settings in which a child actively participates. Relationships between home, school and peer groups may have decisive influences on a child's health-related development. Findings concerning physical activity suggest that socialisation experiences related to having physically active parents, siblings and friends, facilitate making new friends, receiving good social support from significant others and being satisfied with school, are consistently and additively associ- ated with the level of physical activity among children and adolescents (Wold, Aaro \& Smith, 1994:14). Despite general indications that school and social factors influence adolescents' unhealthy behaviours, the association between the school environment and adolescents' health behaviours in South Africa remain largely unknown.

The overall goal of this survey was to increase the understanding of lifestyle and health behaviour within the context of the lives of adolescents in South Africa. Environment, lifestyle and behaviour can interact to influence health. The international HBSC team encourages the participation of African and Asian countries, taking into account specific problems encountered in these regions (Smet, Mouse, De Clerq, Haryanti \& Winarno, 1999:15).

\section{OBJECTIVES}

The main objectives of this study on 'Health Behaviour among School-Aged Children' (HBSC) aimed to:

- collect information on health-related behaviour among South African schoolaged children;

- examine the association between school-aged children's perceptions of their school environment, teachers' and peers' support and their health behaviours; and

- develop recommendations for health promotion activities in schools.

The White Paper on the Transformation of Health Services in South Africa emphasises the development of health promotion practices (Department of Health, 1997:1f.). Coulson (1999:5) notes that the national health promotion policy in draft form aims to (1) put health promotion on the map; (2) promote the approach described in the Ottawa Charter; (3) promote the settings approach for South Africa especially Healthy Schools; (4) identify the scope of activity of health promotion; (5) outline the functions at provincial, regional and district levels. To achieve health promotion the Ottawa Charter (World Health Organisation, 1986:58) outlined five health promotion strategies: (1) building healthy public policy, (2) creating supportive envi 
ronments, (3) strengthening community action, (4) developing personal skills, and (5) reorienting health services. Developing personal skills includes that health promotion supports personal and social development by providing information, education for health, and enhancing skills to take control over their own health and environment. This has to be facilitated in school, home, work and community settings.

The underlying philosophy of the study has been described as a lifestyle approach and differs from classical medical epidemiology (Nutbeam, Aaro \& Wold, 1991:416). No single 'grand theory' of health behaviour among adolescents exists and the study has not been restricted to the concepts or framework of any theoretical model (Nutbeam \& Aaro, 1991:416). There is growing interest in the study of adolescent health and behaviour in different cultures, both within and between countries. It is driven primarily by the ongoing search for social factors that protect youth, impose risks or explain health-related behaviour. However, the attention to social factors in adolescent health research also reflects a general shift in epidemiological surveillance. Early studies, designed to explain infectious diseases, focused on geography, behaviour and biology. More recent studies, designed to explain behaviour, biology and health, add social characteristics such as education, income and family structure to the mix of individual and environmental variables (Michaud, Blum \& Slap, 2001:1239).

\section{METHODS}

\section{Sample and procedure}

The sample comprised (N) 515 Grade 8 secondary school learners chosen at random (sampled within grade and sex, using class registers) from three urban schools in Polokwane, Limpopo Province of South Africa. The Black participants were (n) 267, 102 (38.2\%) male and $165(61.8 \%)$ female learners within the age range of 14 to 18 years (Mean age 15.5 years, $S D=1.6$ ), and the White participants were (n) 248, 108 (43.5\%) male and $140(56.5 \%)$ female learners within the age range of 14 to 18 years (Mean age 15.6 years, $S D=1.6$ ).

Permission was obtained from the Provincial Department of Education and from the school authorities.
Principals of the schools took the ethical responsibility of informing and obtaining permission from the parents of the participants beforehand. Data were collected in 2001 by a self-administered questionnaire in a classroom situation under the supervision of two trained postgraduate research assistants after informed consent had been obtained from the learners. This was done in the form of presenting a covering letter for conducting an anonymous survey to the learners. Only those who consented were asked to fill in the questionnaire. The research assistants introduced themselves and explained the purpose of the survey (Wold et al. 1994:16): "by answering these questions you will help us to find out more about the way in which young people live. Your answers will be looked at by the study team and by no one else. Your parents or teachers will not see them. There is no need to write your name on the questionnaire. Take your time to read each question carefully in turn and answer it as best as you can. Please write down your own answers. Remember that we are only interested in your opinions. This is not a test." No time limit was given, but on average learners took 45 minutes to answer all the questions.

\section{Data collection instruments}

The Health Behaviour among School-Children (HBSC) standard questionnaire has been developed in English by Wold et al. (1994:5-20) for European countries. It has the advantage that it is basically developed for cross-national use. Several studies have been conducted with the HBSC in European countries (Aaro, Wold, Kannas \& Rimpela, 1986:17; Nutbeam et al. 1991:415) but only in one non-Western country namely Indonesia (Smet et al. 1999:7).

Core questions comprise a number of carefully selected behavioural questions relevant to major health problems. These include questions on smoking habits, alcohol use, dental hygiene, eating habits, physical activity and behaviours related to risk of injury. Other items cover psychosocial aspects of health and sociodemographic variables (Wold et al. 1994:1-5).

The questionnaire items were pilot-tested in two focus groups (one with White and one with Black learners) with Grade 8 secondary school learners, who were 
excluded from the actual sample. Each item of the questionnaire was discussed in the two focus groups with the aim of conceptual validity. As a result, the item "use of dental floss" was changed to "use of toothpicks or dental floss" as method of dental hygiene. Then it was given to two external experts to validate and they indicated that the instrument is valid. Further, a pretest was conducted with a sample of 50 Grade eight secondary school learners to test the reliability of the questionnaire. The same learners (from the pretest) were asked to respond to the same questions after three weeks. Test-retest reliability of .83 was found, which is an indication of the reliability of the instrument.

The dependent health-related behaviours included in this study are:

Smoking behaviour. Smoking weekly (at least one cigarette).

Drinking alcohol: Drinking at least one kind of alcoholic beverage monthly (beer, wine, liquor or cider).

Drinking coffee: Drinking coffee weekly.

Unhealthy food consumption (including foods high in fat, salt and/or sugar): One negative point for daily use of each of the following: a) coke or other soft drinks, b) sweets, c) potato crisps, d) chips, and e) hamburgers or hot dogs.

Healthy food consumption (including foods high in fibre): One positive point for daily use of each of the following: a) fruits, b) vegetables, and c) dark/whole wheat bread.

Physical activity: Number of hours of vigorous exercise per week (exercise causing breathlessness or sweating).

Oral hygiene: One positive point for each of the following: a) brushing one's teeth at least twice a day, and b) using toothpicks daily or dental floss daily.

Use of seatbelts: Always use seatbelts when sitting in a car.

An overall test of internal consistency was carried out for the health-related behaviour measure using the statistic called the coefficient of reliability yielding a Cronbach's alpha of .72. Generally, coefficient reliability levels of .70 or more are considered satisfactory (Litwin, 1995:31).

Independent variables included:

Socio-economic status: a) How well off do you think your family is? b) Having a bedroom for oneself; c) Family having a car or van; d) Weekly money to spend on yourself (including pocket money and money you earn yourself); e) Father's occupation; and f) Mother's occupation.

Learners' satisfaction with school indicates the personal outcome of school climate and was measured by a sum score of three variables focusing on learners' evaluation of how satisfied they are with school ('I like school', 'School is a nice place to be' and Going to school is boring'). The first of these variables provided four responses on a Likert scale ('like it a lot', 'like it a bit', 'not very much' and 'not at all'), whereas the two others had five keys ('strongly agree', 'agree', 'neither/ nor', 'disagree' and 'strongly disagree'). The latter ones have been recoded into four response keys in accordance with the distribution and concept of the keys; the categories 'neither/nor' and 'disagree' were collapsed and the others kept in their original form. These variables were added up to produce a total score of 'satisfaction with school' ranging from 0 to 9 where 0 is the lowest satisfaction and 9 the highest. An overall test of internal consistency was carried out for the total score yielding a Cronbach alpha of .76.

Learners' perceptions of the school climate are indicated by how they perceive characteristics of the processes involved in the organisational and relational dimensions and were measured by 14 variables. The first sum score indicates perceptions of the organisational processes of making and exertion of rules, and is named 'Justice in school'. It consists of the following four variables: 'Pupils participate in setting rules', 'The rules are too strict', 'The rules are fair' and 'Teachers treat pupils fairly'. These scores reflect relationships that may be labelled 'Teacher support', 'Learner support' and 'Parent support', respectively. The first indicates leadership support and consists of two variables: 'Teachers give pupils help when needed' and 'Teachers show interest in the pupils'. The second support factor, 'Colleague or Student support', consists of three variables: 'Students enjoy being together', 'Students are kind and helpful' and 'Students accept each other'. Finally, the third support factor 'Parent support' consists of three variables: 'Parents help with school problems', 'Parents are willing to talk to teachers' and 'Parents encourage their children to do well at school'. The learners' perceptions of unreasonable academic demands were measured by two items: 'My teachers 
expect too much of me at school' and 'My parents expect too much of me at school'. In addition, bullying and loneliness during breaks were surveyed through a single item each: 'Have been bullied' and 'Feeling alone at school' (Wold et al. 1994:24-42). The internal consistency analysis for the school climate scale yielded a Cronbach alpha of .79.

\section{Data analysis}

Using the SPSS version 10.0 the Pearson productmoment correlation (Munro \& Page, 1993:175) was used to evaluate relationships between subscales. The Chi-Square test was used for analysis of nominal (categorical) data (Munro \& Page, 1993:82), the t-test for analysis of means for a normal frequency distribution and the Mann-Whitney $U$ test for a skewed distribution (Munro \& Page, 1993:97). The outcome variables were the selected health behaviours, which were dichotomised into healthy and unhealthy categories. To identify independent predictors for the respective healthy behaviour categories multiple logistic regression analyses were performed (Munro \& Page, 1993:196)

Table 1: Health-related behaviour among school-aged children by race and gender in percent

\begin{tabular}{|c|c|c|c|c|c|c|}
\hline Health related behaviour & $\begin{array}{l}\text { Blacks } \\
\mathrm{n}=267\end{array}$ & $\begin{array}{l}\text { Whites } \\
n=248\end{array}$ & $X^{2}$ & $\begin{array}{l}\text { Male } \\
n=210\end{array}$ & $\begin{array}{l}\text { Female } \\
\mathrm{n}=305\end{array}$ & $X^{2}$ \\
\hline Weekly physical activity & 66.3 & 89.5 & $74.78^{\star \star \star}$ & 81.4 & 74.8 & 11.50 \\
\hline Weekly smoking & 3.7 & 15.7 & $31.82^{\star \star \star}$ & 13.3 & 6.9 & $13.55^{\star \star}$ \\
\hline Drinking alcohol monthly & 12.4 & 40.7 & $50.34^{* * *}$ & 33.3 & 21.0 & $9.62^{* *}$ \\
\hline Daily soft drinks & 59.2 & 39.9 & $34.43^{\star \star \star}$ & 52.9 & 47.9 & 6.81 \\
\hline Daily sweets & $\begin{array}{l}71.5 \\
(51.3)\end{array}$ & $\begin{array}{l}39.9 \\
(15.4)\end{array}$ & $84.11^{* * *}$ & $\begin{array}{l}55.7 \\
(27.6)\end{array}$ & $\begin{array}{l}56.7 \\
(37.7)\end{array}$ & $19.72^{\star \star \star}$ \\
\hline $\begin{array}{l}\text { Brush teeth at least twice a } \\
\text { day }\end{array}$ & 66.7 & 80.2 & $14.79^{\star *}$ & 66.6 & 77.7 & $11.07^{*}$ \\
\hline Fruits daily & $\begin{array}{l}68.5 \\
(41.7)\end{array}$ & $\begin{array}{l}69.0 \\
(30.5)\end{array}$ & 7.92 & $\begin{array}{l}68.1 \\
(28.6)\end{array}$ & $\begin{array}{l}69.2 \\
(38.7)\end{array}$ & $14.42^{\star \star}$ \\
\hline Daily raw vegetables & 29.2 & 45.2 & $15.53^{\star \star}$ & 28.6 & 42.6 & $11.48^{*}$ \\
\hline Daily takeaway food & 14.2 & 6.5 & $15.13^{\star \star}$ & 12.9 & 8.9 & 4.79 \\
\hline Drinking coffee weekly & 66.3 & 66.9 & .074 & 72.4 & 62.6 & $13.00^{*}$ \\
\hline Use seatbelts always & 27.7 & 35.1 & 3.16 & 26.7 & 34.5 & 3.32 \\
\hline \multirow[t]{2}{*}{$\begin{array}{l}\text { Injury in past year treated by } \\
\text { doctor/nurse }\end{array}$} & 34.8 & 44.8 & $5.30^{*}$ & 50.0 & 32.5 & $16.00^{\star \star *}$ \\
\hline & $\mathrm{M}(\mathrm{SD})$ & $\mathrm{M}(\mathrm{SD})$ & value & $\mathrm{M}(\mathrm{SD})$ & $\mathrm{M}(\mathrm{SD})$ & value \\
\hline Unhealthy food total score & $\begin{array}{l}2.64 \\
(1.66)\end{array}$ & $\begin{array}{l}1.67 \\
(1.53)\end{array}$ & $Z:-6.43^{* * *}$ & $\begin{array}{l}2.33 \\
(1.68)\end{array}$ & $\begin{array}{l}2.05 \\
(1.64)\end{array}$ & $Z:-1.78$ \\
\hline Healthy food total score & $\begin{array}{l}1.99 \\
(1.20)\end{array}$ & $\begin{array}{l}2.13 \\
(1.05)\end{array}$ & $\mathrm{t}:-.39$ & $\begin{array}{l}1.97 \\
(1.11)\end{array}$ & $\begin{array}{l}2.12 \\
(1.14)\end{array}$ & $\mathrm{t}:-.97$ \\
\hline
\end{tabular}

${ }^{\star * *} p<.001,{ }^{* *} p<.01,{ }^{*} p<.05$ 


\section{RESULTS}

Whites exercised more, smoked more, drank alcohol more often, brushed their teeth more regularly, ate more raw vegetables and sustained more injuries than Blacks. On the other hand, Blacks used more soft drinks, sweets and foods such as burgers and hot dogs than Whites. The Mann-Whitney U test showed that Blacks had a significantly higher unhealthy food score than Whites $(Z=-.645, p<.001)$ but there were no racial differences on the healthy food score $(t=-.39, n s)$. Regarding the different health-related behaviours gender differences were less pronounced than racial differences. There were no significant gender differences regarding the unhealthy and healthy food scores. Men smoked more, drunk more alcohol and coffee and sustained more injuries than women, whereas women ate more sweets, brushed their teeth more often, ate more fruits and raw vegetables than men did.

Pearson correlation showed that teacher's support was associated with the healthy food score $(r=10, p<.05)$ but not with the unhealthy food score $(r=-.05, n s)$, parents' support was negatively associated with the unhealthy food score $(r=-.10, p<.05)$ but not with the healthy food score $(r=-.06, n s)$, peer support as well as socio-economic status were neither related to the healthy food score ( $r=-.04$, ns, and $r-.04$, ns, respectively) nor to the unhealthy food score ( $r=-.02$, ns, and $r=.05$, ns, respectively).

Table 2 shows multiple logistic regression analyses with different health-related behaviours as dependent variables and school-related items as independent variables.

Table 2: School climate in relation to health-related behaviours

\begin{tabular}{|c|c|c|c|c|c|c|}
\hline \multirow[t]{2}{*}{ Health related behaviour } & $\begin{array}{l}\stackrel{0}{0} \\
\stackrel{.0}{5} \\
\stackrel{5}{5}\end{array}$ & 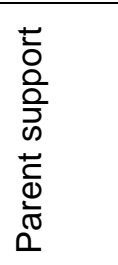 & 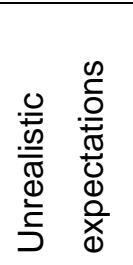 & 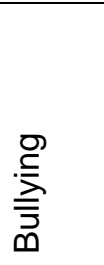 & 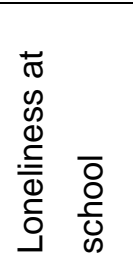 & 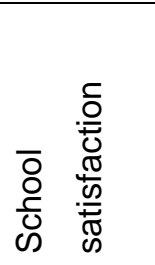 \\
\hline & $O R$ & OR & OR & OR & $O R$ & $O R$ \\
\hline Weekly physical activity & --- & $.75^{\star \star \star}$ & $(-) .81^{*}$ & --- & $(-) .65^{*}$ & --- \\
\hline Weekly smoking & --- & --- & --- & --- & --- & $(-) .77^{\star \star}$ \\
\hline Drinking alcohol monthly & --- & --- & --- & --- & --- & $(-) .84^{\star \star \star}$ \\
\hline Daily soft drinks & --- & --- & $1.16^{\star \star \star}$ & --- & --- & --- \\
\hline Daily sweets & --- & --- & $1.19^{* \star *}$ & --- & $.68^{* *}$ & --- \\
\hline Brush teeth at least twice a day & --- & --- & --- & --- & $(-) .73^{*}$ & --- \\
\hline Fruits daily & --- & $1.13^{*}$ & $1.15^{*}$ & --- & --- & --- \\
\hline Daily takeaway food & --- & --- & --- & $1.26^{*}$ & --- & $1.14^{*}$ \\
\hline Drinking coffee weekly & --- & --- & $1.14^{*}$ & --- & --- & --- \\
\hline $\begin{array}{l}\text { Injury in past year treated by } \\
\text { doctor/nurse }\end{array}$ & $(-) .92^{*}$ & --- & $1.14^{*}$ & $1.23^{*}$ & --- & --- \\
\hline
\end{tabular}

${ }^{* * *} p<.001,{ }^{* *} p<.01,{ }^{*} p<.05 ;$ (-) denotes a negative correlation; socioeconomic status, teacher and student support variables were always not significant and thus not shown here 
Unrealistic expectations by teachers and parents were independent predictors for healthy behaviour (eating fruits) and unhealthy behaviour (eating sweets, drinking soft drinks and coffee, less physical activity and inconsistent or no seat belt use). Loneliness at school was associated with eating more sweets, being physically less active and practising poorer dental hygiene. Dissatisfaction with school was a predictor for smoking and drinking alcohol. Being bullied and experiencing injustice at school was associated with injury during the previous year.

\section{DISCUSSION}

Regarding the prevalence of different health-related behaviour rates found in this study they were generally similar to that found among 15 year-old school children in European countries. However, children in this South African sample seemed to smoke less, drink less alcohol and exercise more often than their European counterparts (Nutbeam et al. 1991:57). Comparing this South African sample with Indonesian 15 yearold learners, in this South African sample $13 \%$ men and $6.9 \%$ women were (weekly) smokers, while $24.7 \%$ of male and $1.7 \%$ of female Indonesian 15 year olds were (weekly) smokers. Among the Indonesian learners only $1.7 \%$ boys and $0.4 \%$ girls drank alcohol weekly, whereas among this South African sample $40.7 \%$ of boys and $21 \%$ of girls reportedly used alcohol within the previous month (Smet et al. 1999:13).

Health-related behaviours of concern were the lack of consistent seatbelt use; among Blacks unhealthy food, eating sweets and drinking soft drinks and among Whites smoking and drinking alcohol. The character of these adolescent health behaviours would indicate undesirable health processes that may lead to serious health problems including chronic respiratory diseases and chronic diseases of lifestyle. These diseases are still preventable or reversible during adolescence (Geckova et al. 2001:643).

This study found that dissatisfaction with school was a predictor for smoking and drinking alcohol. In line with studies among European school children it was found that a majority of 15 year-old respondents reported liking school and that a much smaller proportion of this group were smokers (Nutbeam \& Aaro, 1991:418f.). McLellan, Rissel, Donnelly and Bauman (1999:611) also found among sixth year primary school learners in Australia that learners who had positive perceptions regarding their school environment were significantly more likely to engage in health promoting behaviours.

This finding provides support for a continuation of school-based efforts to reduce smoking and drinking alcohol directed at the high proportion of children who have a positive view of school and who are unlikely to become regular smokers and/or drinkers in later life. It is possible that programmes directed towards enhancing adolescents' resistance to social pressures to smoke or drink may be helpful in assisting the majority of adolescents to remain non-smokers and non-drinkers.

Unrealistic expectations by teachers and parents and loneliness at school were identified as independent predictors for various health-related behaviours. Samdal, Wold, Klepp and Kannas (2000:141) also found among 15-year-old school children in Finland and Norway that unrealistic demands were significantly associated with health compromising behaviours directly.

\section{LIMITATIONS}

It is a restriction of this study that interpretation of the data cannot be extrapolated beyond the target population in the Limpopo Province. Further, it can also not be generalised to all youths since risk behaviours and health problems may be more prevalent among out-of school youth. The socio-economic status of the adolescents and their parents might have limited the range of results obtained. It is possible that adolescents from more different socio-economic backgrounds might have engaged in different health related behaviours.

\section{RECOMMENDATIONS}

The results from this study indicate the need to carefully consider the timing and content of educational interventions to improve their relevance and to coincide with critical periods of development of individual health behaviours. There is also a need to consider the concept of lifestyles in the planning and development of health education for young people. Educational programmes that address the underlying causes and determinants of behaviour, rather than individual 
behaviours themselves, may offer an effective and efficient method of organising health education for young people (Nutbeam, Aar \& Catford, 1989:323).

Health promotion programmes should address issues of unrealistic expectations from learners, the improvement of the school environment, and important racial and gender differences regarding different health behaviours. In particular, the unhealthy food habits among Black school children, smoking and drinking alcohol as well as the prevention of injuries among White school children should be addressed.

Positive changes to the school setting within an educational framework may lead to demonstrable health improvements. The development of Health Promoting Schools including complementary elements of the school environment, the interaction between the school and learners' homes, and the interaction of the school and the community, can contribute to a school being a health promoting environment (Flisher \& Reddy, 1995:630; Vergnant, Flisher, Lazarus, Reddy \& James, 1998:44).

Further, an extension of the HBSC study to a national level with different school levels is recommended.

\section{Acknowledgements}

The study was supported by a grant from the University of the North. The reviewers of Health SA Gesondheid are thanked for their useful comments.

\section{REFERENCES}

AARO, LE; WOLD, B; KANNAS, L \& RIMPELA, M 1986: Health behaviour in school children: a WHO cross-national survey. Health Promotion, 1(1):17-33.

BRADSHAW, D; BOURNE, DE; SCHNEIDER, M \& SAYED R 1995: Mortality patterns of chronic diseases of life style in South Africa. (In: FURIE, J \& STEYN, K eds. 1995: Chronic diseases of life style in South Africa: Review of research and identification of essential health research priorities. Cape Town: Medical Research Council Technical Report, pp. 5-36).

BRONFENBRENNER, U 1979: The ecology of human development. Cambridge: Harvard University Press.

BRUVOLD, WH 1993: A meta-analysis of adolescent smoking prevention programs. American Journal of Public Health, 83(6):872-880.
COULSON, N 1999: Health promotion. South African Health Review, 1999, Chapter 21. Durban: Health Systems Trust.

DEPARTMENT OF HEALTH 1997: White Paper on Health Systems Transformation. Pretoria: Department of Health.

FLISHER, AJ \& REDDY, P 1995: Towards health promoting schools in South Africa. South African Medical Journal, 85(7):629-630. FLISHER, AJ \& CHALTON, DO 2001: Urbanisation and adolescent risk behaviour. South African Medical Journal, 91(3):243249.

FLISHER, AJ; ZIERVOGEL, CF; CHALTON, DO; LEGER, PH \& ROBERTSON, BA 1993a: Risk-taking behaviour of Cape Peninsula high-school students. Part IV. Alcohol use. South African Medical Journal, 83(7):480-482.

FLISHER, AJ; ZIERVOGEL, CF; CHALTON, DO; LEGER, PH \& ROBERTSON, BA 1993b: Risk-taking behaviour of Cape Peninsula high-school students. Part III. Cigarette smoking. South African Medical Journal, 83(7):477-479.

GECKOVA, A; TUINSTRA, J; PUDELSKY, M; KOVAROVA, M; VAN DIJK, JP; GROOTHOFF, JW \& POST, D 2001: Self-reported health problems of Slovak adolescents. Journal of Adolescence, 24(5): 635-645.

GRAHAM, MV \& UPHOLD, CR 1992: Health perceptions and behaviors of school-age boys and girls. Journal of Community Health Nursing, 9(2):77-86.

KING, A; WOLD, B; TUDOR-SMITH, C \& HAREL, Y 1996: The health of youth - a cross-national study: a report of the 1993-4 HBSC survey. (In: WHO regional publications, European Series No. 69. Copenhagen: WHO.)

LITWIN, MS 1995: How to measure survey reliability and validity. London: Sage Publications.

MCLELLAN, L; RISSEL, C; DONNELLY, N \& BAUMAN A 1999: Health behaviour and school environment in New South Wales, Australia. Social Sciences \& Medicine, 49(5):611-619.

MEDICAL RESEARCH COUNCIL (South Africa) 1998: South Africa demographic and health survey. Cape Town: Medical Research Council.

MENDDOZA, R; BATISTA-FOGUET, JM \& OLIVA A 1994: Lifestyles of European school children: findings of the WHO crossnational study on health-related behaviour. (In: DAUWALDER, JP ed. 1994: Psychology and promotion of health. Bern: Hogrefe \& Huber, pp. 8-20).

MICHAUD, P-A; BLUM, RW \& SLAP, GB 2001: Cross-cultural surveys of adolescent health and behaviour: progress and problems.

Social Science \& Medicine, 53(9):1237-1246.

MUNRO, BH \& PAGE, EB 1993: Statistical methods for health care research. Philadelphia: JB Lippincott.

NUTBEAM, D 1997: Indicators of adolescent health: expanding the framework for assessing health status among young people. Pro 
motion \& Education, 4(4):10-14.

NUTBEAM, D \& AARO, LE 1991: Smoking and pupil attitudes towards school: the implications for health education with young people. Results from the WHO study of health behaviour among school children. Health Education Research, 6(4):415-421.

NUTBEAM, D; AAR, L \& CATFORD, J 1989: Understanding children's health behaviour: the implications for health promotion for young people. Social Science \& Medicine, 29(3):317-325.

NUTBEAM, D; AARO, LE \& WOLD, B 1991: The lifestyle concept and health education with young people: results from a WHO international survey. World Health Statistics Quarterly, 44(2):55-61. PELTZER, K; CHERIAN, VI \& CHERIAN, L 1999: Substance use among urban secondary school pupils in South Africa. Southern African Journal of Child \& Adolescent Mental Health, 11(1):49-55.

REDDY, P; MEYER-WEITZ, A \& YACH, D 1996: Smoking status, knowledge of health effects and attitudes towards tobacco control in South Africa. South African Medical Journal, 86(11):13891393.

RESNICK, MD; BEARMAN, PS; BLUM, RW; NAUMAN, KE; HARRIS, KM; JONES, J; TABOR, J; BEUHRING, LH \& UDRY, R 1997: Protecting adolescents from harm: findings from the national longitudinal study on adolescents. Journal of the American Medical Association, 278(10):823-832.

SAMDAL, O; WOLD, B; KLEPP, KI \& KANNAS, L 2000: Students' perception of school and their smoking and alcohol use: a crossnational study. Addiction Research, 8(2):141-167.

SMET, B; MOUSE, L; DE CLERQ, L; HARYANTI, K \& WINARNO, D 1999: The health behaviour in school-aged children study in Semarang, Indonesia: methodological problems in cross-cultural research. Health Promotion International, 14(1):7-16.

STEPTOE, A \& WARDLE, J 1992: Cognitive predictors of health behaviour in contrasting regions of Europe. British Journal of Clinical Psychology, 31(4):485-502.

VERGNANT, T; FLISHER, A; LAZARUS, S; REDDY, P \& JAMES, $S$ 1998: Health promoting schools in South Africa: Needs and prospects. Southern African Journal of Child and Adolescent Mental Health, 10(1):44-58.

WARREN, CW; RILEY, L; ASMA, S; ERIKSON, MP; GREEN, L; BLANTON, C; LOO, C; BATCHELOR, S \& YACH, D 2000: Tobacco use by youth: a surveillance report from the Global Youth Tobacco Survey project. Bulletin of the World Health Organization, 78(7):868-876.

WOLD, B; AARO, LE \& SMITH, C 1994: Health behaviour in schoolaged children: a WHO cross national survey (HBSC). Bergen: University of Bergen.

WORLD HEALTH ORGANISATION 1986: Ottawa Charter for Health Promotion. Copenhagen: WHO. 